Ю Б И Л Е И

УДК $821.511 .132-1$

Г. К. Лисовская

«В ПОИСКАХ ИДЕАЛА ЛИЧНОСТИ»

(К ЮБИЛЕЮ Н. А. БУРИЛОВОЙ)

Статья посвящена жизни и научному творчеству известного коми учёного-литературоведа, кандидата филологических наук Надежды Афанасьевны Буриловой, внесшей большой вклад в развитие литературоведческих исследований в Республике Коми.

Ключевые слова: коми проза, нравственно-эстетический идеал, национальное своеобразие, концепция личности.

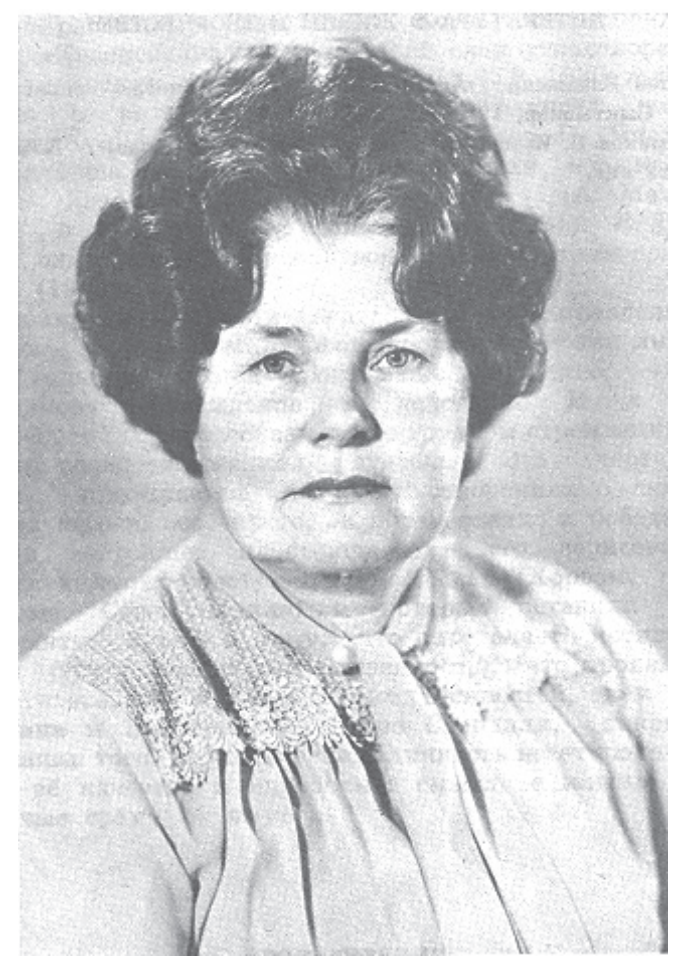
ли около дома. Дом снесли в 1964 г. Среди соседей по дому были: сын Виктора Савина Вениамин Викторович с семьей, первая коми писательница Устинья Попова, переводчик Фёдор Шадрин». 
После школы коми девушка поступила на историко-филологический факультет Кишинёвского университета. Когда во время защиты её кандидатской диссертации ректор Мордовского университета поинтересовался, как она попала в Молдавию, Надежда Афанасьевна пошутила: «Хотела убедиться, что яблоки растут на деревьях...». В её памяти осталось общение с писателями Н. Тихоновым, М. Шолоховым. В годы ее учебы в Кишиневском университете регулярно организовывали встречи с выдающимся деятелями культуры СССР.

По окончании университета Н. А. Бурилова вернулась в Сыктывкар, устроилась работать на радио, где журналистами в то время трудились коми писатели И. Торопов, Г. Юшков, П. Шахов, В. Ширяев. Журналистскую деятельность она продолжила на Сыктывкарской студии телевидения. Затем Надежда Афанасьевна вела педагогическую работу: сначала учителем литературы в школе-интернате, в 1968-1975 гг. - на кафедре педагогики и психологии Коми пединститута. В эти годы произошла её встреча с выдающимся российским педагогом, членомкорреспондентом Российской Академии образования, членом-корреспондентом Академии педагогических наук, народным учителем СССР А. А. Каталиковым, и его женой и соратницей И. В. Плаксиной. В творческом тандеме педагогов-новаторов, «плывущих против течения», Н. А. Бурилова нашла единомышленников и друзей на всю жизнь. И с этого времени она вплотную подходит к научной сфере, связанной с духовной жизнью человека.

В августе 1975 г. Н. А. Бурилова переводится на работу в сектор литературы и фольклора Института языка, литературы и истории, в том же году поступает в заочную аспирантуру Коми филиала АН СССР. Под руководством доктора филологических наук, профессора А. К. Микушева пишет кандидатскую диссертацию на тему «Нравственно-эстетический идеал в современной коми литературе» и в 1983 г. защищает её в Мордовском госуниверситете. Ее работу высоко оценили специалисты, назвав новым словом в финно-угорском литературоведении. Ведущий исследователь финно-угорских литератур народов России, мордовский ученый, профессор Н. И. Черапкин в книге «Доктор литературы» (Саранск, 1996) написал, что Н. А. Бурилова «<...> выдвинула смелую проблему и, главное, доказала её». В условиях идеологического давления, особенно при исследовании литературных эпических жанров, запечатлевших большие исторические периоды в жизни страны и отдельного человека, Надежда Афанасьевна сосредоточила свое внимание не на идеологических вопросах, а на изучении становления национального характера, его эволюции, глубинной связи коми человека с природой, на исторических потрясениях и оставшихся от них в национальной памяти «рубцах». Как обобщение всех раздумий о коми человеке - исследование национального нравственного и эстетического идеала. Это направление она сделала главным в своей исследовательской деятельности.

Перу Н. А. Буриловой принадлежит более ста работ, из них две монографии: «В поисках идеала личности» (1987) и «Не погаси в себе огня» (2000). Предметом изучения стала коми проза лучших коми прозаиков Г. Юшкова, И. Торопова, Н. Куратовой, П. Шахова. Она является одним из авторов «Истории коми литературы» (1980), энциклопедического словаря для школьников «Коми литература» (1995), биобиблиографического словаря «Писатели Коми» в 2-х т. (1996, 2000), соавтором таких научных изданий, как «Анатолий Константинович Микушев» (1998), «Творчество В. Савина и современность». Её статьи печатались в газетах и журналах «Литературная Россия», «Литературное обозрение», «Север», «Войвыв кодзув» (Северная звезда), «Красное знамя», в сборниках научных трудов, научно-методических материалах и т.д.

Усилия Н. А. Буриловой были направлены на исследование национального своеобразия коми литературы. Выявляя черты характера, психологии, нравов, принципов народной педагогики коми на основе коми прозы, она показывает вклад коми в представление об общечеловеческом идеале личности. В первой своей монографии «В поисках идеала личности» роман В. Юхнина «Алая лента», который всегда определяли как историко-революционный, Н. А. Бурилова характеризует как великий национальный роман о судьбах народа. Изучение эпического жанра (на примере романов «Чугра», «Родовой знак» Г. Юшкова, «Вам жить дальше» И. Торопова) становится центральным в ее исследованиях. Она доказывает, что философский 
роман демонстрирует зрелость национальной культуры. Воплощая национально-самобытные, неповторимые типы личности, произведения Г. Юшкова и И. Торопова, по утверждению исследователя, отразили живую историю коми народа, его языка; они прямо ставят актуальную сегодня проблему сохранения коренного народа, его выживания в трагически сложившихся социально-экономических, демографических и экологических условиях.

В 1990-е гг. диапазон исследований Н. Буриловой расширяется: она включается в куратоведение, обращает внимание на произведения К. Жакова: исследует, возможно, самую важную ипостась его духовного наследия - этические взгляды писателя. Приметой ее работ становится внимание к творческому наследию профессора А. И. Микушева, которому посвящена серия статей. Её глубокие познания в педагогике и психологии открывали новые перспективы в изучении человеческого характера, процесса формирования личности, ориентиров его существования и значительно обогащали исследования.

Надежда Афанасьевна любит писателей, о которых пишет; для нее важна личность писателя, его биография. Какие-то ключевые моменты в жизни авторов, которые дают импульс для создания произведений, Надежда Афанасьевна обнаруживает и вводит в контекст своих литературоведческих работ. Так, рассматривая в монографии «В поисках идеала личности» книгу И. Пыстина «Фронтовые дни и ночи», она обращается к неопубликованным дневникам писателя, предоставленным его вдовой; для характеристики романа В. Юхнина «Алая лента» исследователь изучает письма автора; анализируя произведения И. Торопова, П. Шахова, соотносит их с определенными периодами биографии писателей. Её работа с произведениями коми писателей включает в себя всестороннее проникновение в их творческую мастерскую.

Проблема любой области знания - это проблема личности. Не случайно Н.А. Бурилова обращается к исследованию концепции личности в коми литературе. Личность - это внутренняя свобода, независимость и личная ответственность. Именно этими качествами обладает Надежда Афанасьевна. Ею невозможно было манипулировать, поэтому путь ученого был не прост. Н. А. Бурилова умела мужественно отстаивать свои идеалы, но при этом своим талантом исследователя могла растопить сердце самого сурового оппонента. Так, очень точным и проникновенным погружением в ткань романа В. Юхнина «Алая лента», совершенно уникальной реконструкцией характера коми охотника, его нравственного кодекса, она вызвала восхищение скупого на похвалу выдающегося фольклориста Ф. В. Плесовского, который сказал на обсуждении ее работы: «Об «Алой ленте» писали многие, но так, как у Надежды Афанасьевны не было».

Мерилом научности для литературоведа становится доскональная работа с художественным фактом. Н. Бурилова стремится осмыслить язык писателей с исчерпывающей полнотой. Особенно тщательно Надежда Афанасьевна изучает язык произведений Геннадия Юшкова. Через «любовное» вчитывание в его тексты она постигает философию писателя, доминанты его мышления. Романы «Чугра», «Родовой знак» рассмотрены ею с таким трепетным вниманием к каждой детали, так ярко, с глубоким погружением в художественный мир писателя, что на сегодняшний день эти работы исследователя являются непревзойденными. Переиздание трудов Надежды Афанасьевны необходимо для учителей школ, преподавателей вузов, это позволило бы им опираться на них как на методологическую основу при изучении творчества коми писателей. Вспоминается, с каким вниманием слушали преподаватели выступления Н. А. Буриловой на научно-практических конференциях. Ее выделяли среди других докладчиков и в перерывах окружали, обращались со словами благодарности.

В работах ученого впервые получила освещение та область межличностных отношений, которую теперь принято называть гендерной. Так, Н. А. Бурилова утверждает, что у В. Юхнина отношение к женщине становится критерием индивидуальной нравственности и одновременно показателем социальной зрелости героев. Глубокие размышления ученого о коми-зырянке в национальной прозе - это размышления об истоках жизнестойкости коми народа. 
Имея опыт журналистской деятельности, Н. А. Бурилова показала себя и как блестящий критик. Литературные колонки в «Красном знамени» в 1970-е г. читал каждый житель республики. Её статьи «Вечный источник мысли. Размышления о нравственном воспитании» или «Становление личности. Заметки о прозе молодых» явились заметным событием культурной жизни. Особенный общественный резонанс имели её интервью-диалоги с писателем Республики Коми Г. Юшковым, доктором филологических наук В. И. Дёминым. Интерес представляют также газетные рецензии Н. А. Буриловой о прозе молодых коми и русских прозаиков (А. Тарабукина, Е. Габовой, И. Кузнецова). Как критик она участвовала в работе семинаров молодых писателей, организованных Союзом Писателей Коми Республики, была членом редколлегии журнала «Войвыв кодзув» (Северная звезда).

Н. А. Бурилова принимала участие в работе Международных конгрессов финно-угроведов: VI - в Сыктывкаре (1985), VII - в Дебрецене (Венгрия, 1990), VIII - в Ювяскюля (Финляндия, 1995).

Являясь сотрудником Института языка, литературы и истории, Н. А. Бурилова одновременно работала в Сыктывкарском государственном университете, куда была приглашена в качестве преподавателя на финно-угорский факультет. В университете ею был разработан уникальный курс «Литературное краеведение». Когда в апреле 1999 г. была создана культурно-просветительская организация «Сыктывкар», инициатором создания и первым председателем Совета которой был доктор филологических наук В. И. Дёмин, Н. А. Бурилова вошла в ее правление. Её обширные знания культурной жизни города, креативность мышления дают импульс многим начинаниям этой влиятельной общественной организации по сохранению национального культурного наследия. Являясь коренной жительницей Сыктывкара, чьё детство прошло в окружении многих известных людей того времени, она и впоследствии оказалась среди культурной элиты города. Её муж, Геннадий Васильевич Бурилов - заслуженный работник культуры Республики Коми, входил в первый состав артистов балета Музыкального театра (ныне Государственного театра оперы и балета), работал с момента его открытия 26 августа 1950 г. Надежда Афанасьевна хорошо знает культурный ландшафт Сыктывкара начиная с конца 1950-х г. - времени культурного подъема в столице республики, ведущую роль в котором играли, в том числе, крупные репрессированные деятели культуры страны.

Учёба в «столичном» Кишинёвском университете, общение с выдающимися коми писателями и журналистами, талантливыми деятелями педагогической науки и культуры, а затем с главным учителем ее жизни, научным руководителем А. К. Микушевым, - все это сформировало Н. А. Бурилову как учёного, уникального исследователя коми литературы, сочетающего в себе широту мышления с четким стремлением служить национальной литературе и, по большому счету, коми человеку, его нравственному росту.

«Большая» коми литература, поднимающая бытийные проблемы, нашла в лице Надежды Афанасьевны блестящего толкователя. Она увидела в ней доминирующее этическое начало. Гуманистический пафос «благоговения перед жизнью» (А. Швейцер) как высшее начало этики, проходящий через все её исследования коми литературы, становится сегодня сверхактуальным.

Проблема личности, решаемая в её трудах, включает в себя философское и психологическое содержание, и благодаря этому проблема становится объемной, а её решение не может быть однозначным. Н. А. Бурилова раскрывает бесконечный потенциал человека. Нравственноэстетический идеал народа, сохраняемый на протяжении лет и веков испытаний, - это высшее проявление его сущности, утверждает в своих работах литературовед. Труды Надежды Афанасьевны, в которых есть ответы на вызовы современности, сегодня, в начале XXI в., еще более актуальны, чем во второй половине XX в.

Поздравляем Надежду Афанасьевну Бурилову с юбилеем, желаем ей крепкого здоровья, и пусть дух творчества никогда не оставляет её! 
Лисовская Галина Константиновна, научный сотрудник сектора литературоведения, Институт языка, литературы и истории ФИЦ «Коми НЦ УрО РАН», 167982, Россия, г. Сыктывкар, ул. Коммунистическая, 26, e-mail: lisovskaya1330@gmail.com

\section{G. K. Lisovskaya \\ «IN SEARCH OF THE IDEAL OF PERSONALITY» \\ (FOR ANNIVERSARY OF N. A. BURILOVA)}

DOI: $10.35634 / 2224-9443-2021-15-2-362-366$

The article is devoted to the life and scientific work of the famous Komi scholar-literary critic, candidate of philological sciences Nadezhda Afanasyevna Burilova, who made a major contribution to the development of literary studies in the Komi Republic.

Key words: Komi prose, moral and aesthetic ideal, national identity, concept of personality.

Citation: Yearbook of Finno-Ugric Studies, 2021, vol. 15, issue 2, pp. 362-366. In Russian.

Reseived 30.03.2021

Lisovskaya Galina Konstantinovna,

Researcher, Sector of Literary Criticism, Institute of Language, Literature and History of the Komi Science Centre of the Ural Branch of the

Russian Academy of Sciences, 26, ul. Kommunisticheskaya, Syktyvkar, 167982, Russian Federation, e-mail: lisovskaya1330@gmail.com 